Available Online : https://proceeding.researchsynergypress.com/index.php/cset/index

RSF Conference Series: Engineering and Technology

ISSN 2809-6843 (Online) | 2809-6878 (Print)

Volume 1 Number 1 (2021): 244-247

\title{
Koja Banana Plantlet Acclimatization at Various Concentrations of Foliar Fertilizer and Length of Containment
}

\author{
Rina Srilestari, Suwardi \\ Faculty of Agriculture, National Development University "Veteran" Yogyakarta.
}

\begin{abstract}
Koja is a widely known variety of bananas but the availability of high-quality seeds has not been able to meet the market demand. This problem is overcome by using tissue culture, meanwhile, the success of the culture is largely determined by the acclimatization stage or adaptation of plants from heterotrophs to autotrophs. Therefore, this study aims to determine the interaction between the concentration of foliar fertilizer and the length of containment as well as the appropriate concentration for the growth of Koja banana plantlets. This is a field experiment carried out with a 2 -factors split-plot design. The main plot was the foliar fertilizer concentration namely M1 = $2 \mathrm{ml} / \mathrm{L}$; $\mathrm{M} 2=4 \mathrm{ml} / \mathrm{L} ; \mathrm{M} 3=6 \mathrm{ml} / \mathrm{L}$, while the subplots were the length of containment namely E1 = 10 days; $\mathrm{E} 2=20$ days; $\mathrm{E} 3=30$ days. Based on the results, there was an interaction between the concentration of foliar fertilizer $4 \mathrm{~mL} / \mathrm{L}$ and the length of containment of 20 days on the height, root volume, as well as fresh and plant dry weight.
\end{abstract}

Keywords: Koja Banana, Acclimatization, Foliar Fertilizer, Length of Containment

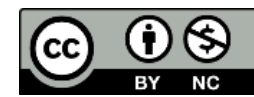

This is an open access article under the CC-BY-NC license

\section{INTRODUCTION}

Bananas are one of the fruit commodities widely consumed due to the cheap price and good nutritional quality. Several parts of the plant have potential benefits such as the fruit which is consumed, the undeveloped flowers as vegetables, and the leaves for wrapping food. Furthermore, the harvested area and banana production rank first in relation to the total production of other fruits (12).

Koja banana is a widely cultivated variety but the cultivation needs to be supported by innovation or appropriate technology. The conventional method of plant propagation using weeds or tillers only produces seeds in small quantities (5-10 seedlings per clump per year), takes a long time, is not uniform, and is not entirely free from disease and pests. However, these problems are overcome by utilizing in vitro culture (4).

In vitro culture has several advantages, including providing large quantities of seeds, retaining the parents' characteristics, producing seeds free of pests and diseases, as well as good uniformity of planting material. The success of plantlets growth in the culture is largely determined by the acclimatization stage (4).

Acclimatization of plant plantlets is the process of adapting to a transition from a controlled to an uncontrolled environment through in vitro techniques. Plantlets maintained in controlled conditions with the optimal environment (temperature and humidity), are very susceptible to high transpiration and die easily when exposed to an uncontrolled environment, therefore, acclimatization is required to adapt the plantlets to field conditions (1).

The acclimatization stage needs to be carried out for growth and development to obtain new plants that are ready to be planted in the field (8). The plant at this stage is very weak, therefore, nutrients are added to increase growth by spraying foliar fertilizers (9). In addition, it is necessary to adapt the plants by reducing air humidity and gradually increasing the light intensity through contaiment(8) 


\section{LITERATURE REVIEW}

Acclimatization aims to adapt seedlings grown by in vitro culture to an autotrophic environment. It is carried out by transferring plantlets to media with low light intensity and high relative humidity, then gradually lowering the humidity and increasing the light intensity. Factors that affect plantlet growth include planting media, light intensity, nutrient content, humidity, and room temperature (7).

Meanwhile, fertilization aims to provide nutrients for optimal plant productivity through the application on the leaves or the soil. Leaves application is more effective given that it allows about $90 \%$ absorption of the fertilizer, while the roots only absorb $10 \%$. When applying fertilizer in liquid form, the concentration of the solution given needs to be considered, as each plant species has a different level of need (6).

Containment is required to maintain temperature, humidity, stability, as well as to prevent pests and diseases. It is carried out in two ways namely single for a specific plant and mass for all plants. The single approach is more beneficial given that the temperature and humidity are stabilized, while the mass is more practical (2).

\section{RESEARCH METHOD}

The materials used include Koja banana plantlets aged 4 months, sand, compost, vitamin B1, leaf fertilizer, clear plastic, plastic straws, sprayers, scales, oven, camera, ruler, label, and stationery.

This study is a field experiment with a 2-factor split-plot design method. The first factor is the concentration of foliar fertilizer which consists of 3 levels namely $2 \mathrm{ml} / \mathrm{L}, 4 \mathrm{ml} / \mathrm{L}$, and $6 \mathrm{ml} / \mathrm{L}$ while the second factor is the length of containment which also consists of 3 levels namely 10 days, 20 days, and 30 days. Furthermore, the data were analyzed by Analysis of Variance at 5\% level and further tested with DMRT 5\%.

The plantlets were planted in plastic pots filled with sand and compost (1:1), stored according to treatment, sprayed with foliar fertilizer 31 days after planting in the morning vitamin B1 once a week.

\section{FINDING AND DISCUSSION}

Fertilizer application with a concentration of $4 \mathrm{ml} / \mathrm{L}$ and length of contaiment of 20 days showed significant effects on plant height, root volume, as well as fresh and dry weight as shown in Table 1.

Table 1. Average plant height (cm), Root Volume (mL), Plant Fresh Weight (g), and Dry Weight (g) at various concentrations of foliar fertilizer and length of containment

\begin{tabular}{|c|c|c|c|c|}
\hline \multirow{2}{*}{ Treatment } & \multicolumn{4}{|c|}{ Average } \\
\hline & Plant Height (cm) & $\begin{array}{l}\text { Root Volume } \\
\text { (mL) }\end{array}$ & $\begin{array}{l}\text { Plant Fresh } \\
\text { Weight (g) }\end{array}$ & $\begin{array}{c}\text { Plant Dry Weight } \\
\text { (g) }\end{array}$ \\
\hline M1E1 & $99,67 \mathrm{bc}$ & $52,33 \mathrm{e}$ & $302,00 \mathrm{~d}$ & $14,00 \mathrm{~d}$ \\
\hline M1E2 & $97,00 \mathrm{bc}$ & $68,67 \mathrm{c}$ & $448,40 \mathrm{~b}$ & $27,77 \mathrm{bc}$ \\
\hline M1E3 & $104,33 \mathrm{bc}$ & 57,33 de & $406,73 \mathrm{c}$ & $21,13 \mathrm{c}$ \\
\hline M2E1 & $107,00 \mathrm{bc}$ & $99,33 \mathrm{~b}$ & $449,73 \mathrm{~b}$ & $30.33 \mathrm{~b}$ \\
\hline M2E2 & $125,33 \mathrm{a}$ & $125,00 \mathrm{a}$ & 508,33 a & $39.43 \mathrm{a}$ \\
\hline M2E3 & $105,67 \mathrm{bc}$ & $101,67 \mathrm{~b}$ & $431,60 \mathrm{bc}$ & $31,60 \mathrm{~b}$ \\
\hline M3E1 & $101,33 \mathrm{bc}$ & $67,33 \mathrm{~cd}$ & $402,63 \mathrm{c}$ & $22,67 \mathrm{c}$ \\
\hline M3E2 & $109,33 \mathrm{~b}$ & $92,67 \mathrm{~b}$ & $408,83 \mathrm{c}$ & $24,27 \mathrm{c}$ \\
\hline M3E3 & $100,33 \mathrm{bc}$ & 58,67 cde & 415,73 c14 & $21,67 \mathrm{c}$ \\
\hline Interaction & $(+)$ & $(+)$ & $(+)$ & $(+)$ \\
\hline
\end{tabular}


Information: The average followed by the same letter notation in the same column and row showed no significant difference at the 5\% DMRT level. The sign (+) indicates there is an interaction.

The plant height and root volume produced were $125.33 \mathrm{~cm}$ and $125.00 \mathrm{~mL}$, respectively. This shows that there is a synergistic relationship between foliar fertilizer and length of containment. Bio grow fertilizers contain phosphorus, microbes, and auxin growth regulator, the phosphorus function to increase the growth, development, and expansion of the root system to optimize nutrient absorption (14). It also contains microorganisms such as Azotobacter sp., Bacillus sp., Pseudomonas sp., and BPF which dissolve phosphate for plant absorption, while the auxin content enhances plant growth by elongating cells to increase the length, and volume (3).

The larger the root volume, the greater the nutrients absorbed and the taller the plant, this is due to the competition for the absorption of water and nutrients in the root volume. Root growth is improved through absorption, as well as the incorporation of water and nutrients needed for better plant metabolism (10). Furthermore, roots are the main vegetative organs that supply water, minerals, and essential materials for plant growth and development.

The 20 days length of containmentis the right time to open the lid because the plant has passed a critical period in the acclimatization stage. In addition, stem lignification and palisade parenchyma have been formed, while the stomata and carrier bundles functioned perfectly, therefore, the plant responded optimally when sprayed with foliar fertilizer.

The foliar fertilizer treatment of $4 \mathrm{~mL} / \mathrm{L}$ and length of containment of 20 days had the heaviest weight of 508.33 grams. This is because the treatment produced the highest plant height and root volume. Plants require nutrients in sufficient quantities to support growth, meanwhile, the ability to absorb water and nutrients by long roots increases fresh weight (5). Furthermore, the fresh weight is the composition of nutrients and water in a tissue while the dry weight is a growth indicator obtained from the total growth and development of the plant throughout the lifetime.

Proper containment with the right period protects plants from pests or diseases and retain $\mathrm{CO} 2$ gas released during photosynthesis. It also serves to maintain the planting media humidity to prevent rapid loss of water. The major components of photosynthesis namely $\mathrm{CO} 2$ and water use sunlight to convert solar into chemical energy which is then stored in fruits, leaves, stems, and roots as food reserves (13).

Regarding the dry weight, foliar fertilizer treatment of $4 \mathrm{~mL} / \mathrm{L}$ and 20 days length of storage had the heaviest dry weight of 39.43 grams. Dry weight is the value obtained after drying a material and is the accumulation of photosynthate. According to (5), it is a plant growth indicator of assimilates obtained from the total growth and development. Meanwhile, (11) stated that the storage treatment function to maintain the humidity thereby preventing the planting media from rapid water loss.

\section{CONCLUSION AND FURTHER RESEARCH}

Based on the results, the foliar fertilizer concentration $4 \mathrm{~mL} / \mathrm{L}$ and length of containment of 20 days affected plant height, root volume, as well as fresh and dry weight at the acclimatization stage. However, further studies are needed to reproduce these results on the field.

\section{Acknowledgement}

The authors are grateful to the Ministry of Research, Technology, and Higher Education for the assistance with the Higher Education Fundamental Research Funds approved for this Research of UPN "Veteran" Yogyakarta.

\section{REFERENCES}




\section{REFERENCES}

Basri, H., Basri, Z., Syakur A. (2013). Bibit Tanaman Buah Naga (Hylocereus undatus) pada Tingkat Naungan Berbeda. Program Studi Agroteknologi Fakultas Pertanian Universitas Tadulako. Sulawesi Tengah

Izudin, E. (2013). Teknik Aklimatisasi Tanaman Hasil Kultur Jaringan. Yogyakarta. Balai Besar Penelitian Bioteknologi dan Pemuliaan Tanaman Hutan. Jurnal Informasi Teknis 11(2):49-56.

Marista, E., Khotimah, S. D \& Linda, R. (2013). Bakteri Pelarut Fosfat Hasil Isolasi dari Tiga Jen is Tanah Rizosfer Tanaman Pisang Nipah (Musa paradisiaca var. nipah) di Kota Singkawang. Pontianak. Tanjung Pura. Jurnal Protobiont 2(2):93-101.

Pamungkas.( 2015). Pengaruh Konsentrasi NAA dan BAP Terhadap Pertumbuhan Tunas Eksplan Tanaman Pisang Cavendish (Musa paradisiaca L.) Melalui Kultur In Vitro. Politeknik Perkebunan LPP Yogyakarta

Raynalta, E., \& Sukma, D. (20130. Pengaruh Komposisi Media dalam Perbanyakan Protocorm Like Bodies, Pertumbuhan Planlet dan Aklimatisasi Phalaenopsis amabilis. Bogor. Institut Pertanian Bogor. Jurnal Hortikultura Indonesia 4(3):131-139.

Satriyo \& Aini, (2018). Pengaruh Jenis dan Tingkat Konsentrasi Pupuk Daun Terhadap Pertumbuhan dan Hasil Tanaman Terong. Malang. Universitas Brawijaya. Jurnal Produksi Tanaman 6(7):1473-1480.

Sukmadjaya, D., Purnamaningsih, R., \& Priyatno, T. (2013). Pertumbuhan Planlet Kantong Semar (Nepenthes rafflesiana Jack.) pada Beberapa Media Tanam Selama Tahap Aklimatisasi. Bogor. Institut Pertanian Bogor. Jurnal Hortikultura Indonesia 4(3):124-130

Simanjuntak, T. S. (2018). Aklimatisasi Pisang Raja Bulu dengan Berbagai Macam Media Tanam dan Lama Penyungkupan. Universitas Pembangunan "Veteran” Yogyakarta, Fakultas Pertanian.

Sinuraya, M., A., Barus, A. \& Hasanah, Y. (2015). Respons Pertumbuhan dan Produksi Kedelai (Glycine max L.) terhadap Konsentrasi dan Cara Pemberian Pupuk Organik Cair.Medan. Universitas Sumatera Utara. Jurnal Agroteknologi 4(1):1721-1725.

Sitompoel, S.M, \& B. Guritno, (1995). Analisis Pertumbuhan Tanaman. Gajah Mada Universitas Press.

Yogyakarta. 412 hal

Sudartini, T., Zumani, D., \& Diantini, D. (2020). Pengaruh Sungkup dan Jenis Media Tanam terhadap Pertumbuhan Bibit Anggrek Dendrobium saat Aklimatisasi. Tasikmalaya. Universitas Siliwangi. Media Pertanian 5(1):31-43.

Supriati, Y.,( 2010). Efisiensi Mikropropagasi Pisang Kepok Amorang melalui Modifikasi Formula Media dan Temperatur. Bogor. Balai Besar Penelitian dan Perkembangan Bioteknologi. Jurnal AgroBiogen 6(2):91-100.

Wayah, E., Sudiarso \& Soelistyono. (2014). Pengaruh Pemberian Air dan Pupuk Kandang Sapi terhadap Pertumbuhan dan Hasil Tanaman Jagung Manis (Zea mays). Jurnal Produksi Tanaman 2(2):94102.

Wulandari, A \& Susanti, S. (2012). Aplikasi Pupuk Daun Organik untuk Meningkatkan Pertumbuhan Bibit Jabon (Anthocephalus cadamba Roxb. Miq.). Bogor. Institut Pertanian Bogor. Jurnal Silvikultur Tropika 3(2):137-142. 